\title{
Effect of socioeconomic status and institution of the environmental concern level
}

\author{
Zuber Angkasa Wazir ${ }^{1, *}$ \\ ${ }^{1}$ Department of Architecture. Muhammadiyah University of Palembang, 30263 Palembang, Indonesia
}

\begin{abstract}
Development in developing countries should be implemented in a sustainable and responsible. The responsibility not only by the government but also the Society. Society must have a high environmental concern. Therefore, the sociological factors that affect the level of environmental concern must be identified. This study used socio-economic status and social institutions as potential variables affect the level of environmental concern. The study was conducted in three housing in the suburbs, where the land conversion happens on a large scale in the city of Palembang. The level of environmental concern identified by NEP scale which had Cronbach Alpha value of 0.658 . Socio-economic status is represented by the last educational variables and the average monthly income while institutions are represented by profession occupants. Total respondents were 103 heads of households with the majority of high school educated, the average income of IDR 4.3 million per month, and 53 respondents as a trader. Data analysis using linear regression. The analysis showed that the negative effect of institutions while the socio-economic status did not affect the level of environmental concern. These results show the importance of sociological intervention of institutions that positively affects the level of environmental concern.
\end{abstract}

\section{Introduction}

In developing countries, the discourse of responsible and sustainable development is an important discourse in an effort to meet the needs of the present without compromising the ability of future generations to meet their own needs [1]. Even so, it is difficult to achieve because of human behavior in developing countries experiencing a transition between state-oriented environment (agrarian or maritime) to the industrial countries. New emerging society moved from an era that basically is already ongoing, but the offer of consumerism and industrialization irresponsible provide hedonic desire in an atmosphere that is still sustainable environment. Consequently, the reluctance to adopt a sustainable development that seeks to be more careful in the exploitation of natural resources and behavioral development in general.

Their behavioral deficits such as these require corrective steps are involving elements of the government in order to reach the public in a large scope. Hopefully, with the gap being filled public awareness can lead to the creation of sustainable behavior so that development can be more certain in the future.

In line with this, studies in psychology and sociology neighborhood went on efforts to assess aspects of the physical-biological process of the physical environment of nature, increasing complexity of spatial-physical for their aspects of socio-physical that need to be considered in the study, as well as their paramount concern in behavior and actions in everyday human environment in relation to natural resources or processes in nature considered ecologically sustainable [2]. The present study attempted to assess the factors of socio-economic and social institutions in their influence on one of the indicators in environmentally friendly behavior which is the level of environmental awareness.

The study was conducted in Palembang, Indonesia. Palembang is a city that is growing rapidly, characterized by the growth of housing in large quantities. Residential neighborhood that continues to grow is to produce a large-scale land conversion. Originally, the land around and in Palembang itself is so marshy that practically the main transportation is unreliable public transport streams [3]. Since the 20th century, large-scale changes to the conversion of wetlands into housing in the suburbs and in the city give the effect of flooding. Indeed so, the City government strives to increase public awareness of the environment in a multi-ethnic city. Various physical programs conducted as forming a city park or clean-up activities on a regular basis. Even so, the psycho-sociological aspects still less untouched. therefore, this study sought to touch this aspect by highlighting the factors that can affect the level of public environmental concern in Palembang.

\section{State of the art}

In 1978, Dunlap and Van Liere filed New Environmental Paradigm Scale (NEP scale) to measure the belief that humans are part of nature that they should preserve it

Corresponding author: zuberpalembani@gmail.com 
and avoid exploitation of natural resources [2]. NEP scale is a belief system embedded and difficult to change on an individual regarding his perspective on the environment. NEP scale measure the ecological core beliefs as their ecological limits and the importance of maintaining the balance of nature [2].

In its development, the NEP scale was found significantly associated with pro-environmental behavior [2]. Therefore, we can approach the NEP scale as a form of human values guide to describe their behavioral tendencies pro-environment.

Previous research has identified several demographic variables that influence individual attitudes toward the attitude towards the environment [4]. These variables are generally weak and sometimes inconsistent between populations. Among them, the respondents were young and highly educated tend to be more positive about environmental issues $[4 ; 5]$. Women tend to be more proenvironment than men [6;7]. Certain ethnic groups in care more about the environment than other ethnic groups [4]. High socioeconomic status and ethnic origin majority (elitism) tend to have a positive attitude towards the environment [4]. Meanwhile, other studies have shown that social context influence the behavioral expression of an attitude, such as between ethnic groups with environmentally friendly behavior [8].

The social institution itself is a means of transmitting norms, values, beliefs, habits, and so on between generations [9]. That is, social institutions is an effective tool to raise a certain world view, including new ecological paradigm. Social institutions themselves structure the availability of social and economic incentives in the community for a certain behavior or attitude [10].

Changes in society created mainly through the support of social institutions that contain systems of values stored in social institutions. Social institutions increasingly important role in modern society is a society of risk. Risk society characterized by a fragmented view and there is competition between institutions and values. It can be said, containing risk society institutions that pro-environment, are vying for dominance. Such a society is going to be tough when pro-environmental institutions able to control the entire system in a holistic and integrated [11]. This is because social institutions, especially if tied to a spatial context, will be a significant impact on the lives of community members [12].

Indeed so, the literature is still saying that there is still much to be learned from the relationship between a social institution with human individuals [12]. This can include the relation between the social institutions in influencing new ecological paradigm embraced by the community. A close relationship should signify that social institutions that surround the community have been effective in encouraging the development of proenvironmental paradigm. Conversely, if there is a close relationship, it can be said that the spatial context that surrounds the pro-environmental regulation cannot support the development paradigm of the environment in the community.

As the description above, this study will examine the relationship between socioeconomic characteristics and social institutions of the community with new ecological paradigm scale (referred to as Environmental Concern Level) that embraced by the community

\section{Data collection}

This study collected data from three housing in the city of Palembang, namely Taman Sari Kenten (TS), Talang Kelapa (TK), and Taman Ogan Permai (TOP). Housing projects have been selected because they exhibit the same characteristics in locations on the outskirts of Palembang. In addition, residential housing is classified as having the occupants of diverse backgrounds. The housings are shown by the following data:

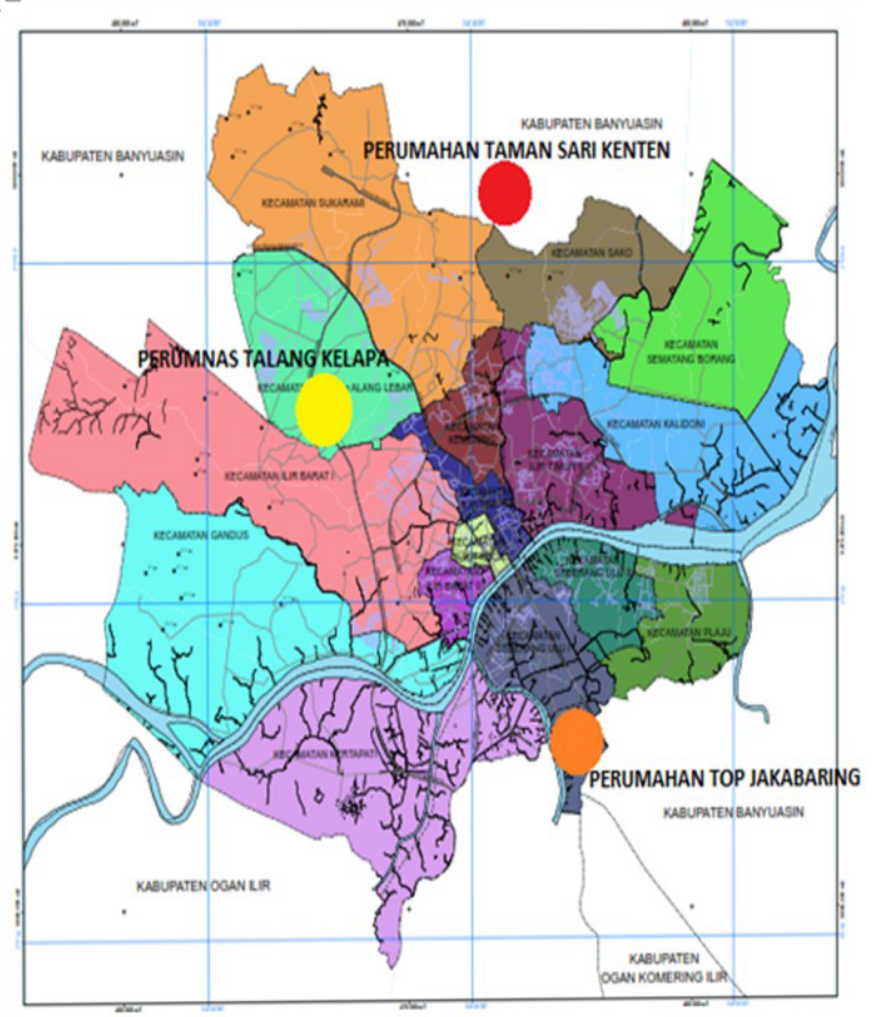

Fig. 1. Research sites on the city of Palembang Source : [13], with modifications

The data source is the residents of the house in this residential area. One unit of data representing the randomly selected homes by housing blocks. It can be seen to be representative because it avoids some individuals represent one family. The total sample was 103 homes.

\section{Methodology}

\subsection{New environmental paradigm scale}

NEP scale applied in this study after a pass from the validity and reliability. Validity and reliability of data using SPSS software version 20 executed after data collected from residents by questionnaires. The options are Strongly Agree, Agree, Do not Know, Disagree and Strongly Disagree. NEP scale instruments shown in Table 1. 
Table 1. NEP scale instruments

\begin{tabular}{|c|c|c|}
\hline Descriptive & Dimensions & $\begin{array}{l}\text { Item No. } \\
\text { Question }\end{array}$ \\
\hline \multirow[t]{3}{*}{$\begin{array}{l}\text { Limits on } \\
\text { Humans Growth }\end{array}$} & $\begin{array}{l}\text { We are approaching } \\
\text { the limit of the number } \\
\text { of people the Earth can } \\
\text { support }\end{array}$ & 1 \\
\hline & $\begin{array}{l}\text { The Earth has plenty } \\
\text { of natural resources if } \\
\text { we just learn how to } \\
\text { develop them }\end{array}$ & 2 \\
\hline & $\begin{array}{l}\text { The Earth is like a } \\
\text { spaceship with very } \\
\text { limited room and } \\
\text { resources }\end{array}$ & 3 \\
\hline \multirow[t]{3}{*}{$\begin{array}{l}\text { The dominance } \\
\text { of humans in } \\
\text { nature }\end{array}$} & $\begin{array}{l}\text { Humans have the right } \\
\text { to modify the natural } \\
\text { environment to suit } \\
\text { their need }\end{array}$ & 4 \\
\hline & $\begin{array}{l}\text { Plants and animals } \\
\text { have as much right as } \\
\text { humans to exist }\end{array}$ & 5 \\
\hline & $\begin{array}{l}\text { Humans were meant to } \\
\text { rule over the rest of } \\
\text { nature }\end{array}$ & 6 \\
\hline \multirow[t]{3}{*}{$\begin{array}{l}\text { The balance of } \\
\text { nature }\end{array}$} & $\begin{array}{l}\text { When humans } \\
\text { interfere with nature it } \\
\text { often produces } \\
\text { disastrous } \\
\text { consequence }\end{array}$ & 7 \\
\hline & $\begin{array}{l}\text { The balance of nature } \\
\text { is strong enough to } \\
\text { cope with the impacts } \\
\text { of modern industrial } \\
\text { nations }\end{array}$ & 8 \\
\hline & $\begin{array}{l}\text { The balance of nature } \\
\text { is very delicate and } \\
\text { easily upset }\end{array}$ & 9 \\
\hline \multirow[t]{3}{*}{$\begin{array}{l}\text { Humans } \\
\text { Exemptionalism }\end{array}$} & $\begin{array}{l}\text { Humans ingenuity will } \\
\text { ensure that we do not } \\
\text { make the Earth } \\
\text { unlivable }\end{array}$ & 10 \\
\hline & $\begin{array}{l}\text { Despite our special } \\
\text { abilities, humans are } \\
\text { still subject to the laws } \\
\text { of nature }\end{array}$ & 11 \\
\hline & $\begin{array}{l}\text { Humans will } \\
\text { eventually learn } \\
\text { enough about how } \\
\text { nature works to be able } \\
\text { to control it }\end{array}$ & 12 \\
\hline \multirow[t]{3}{*}{ Ecocrisis } & $\begin{array}{l}\text { Humans are seriously } \\
\text { abusing the } \\
\text { environment }\end{array}$ & 13 \\
\hline & $\begin{array}{l}\text { The so-called } \\
\text { "ecological crisis" } \\
\text { facing humankind has } \\
\text { been greatly } \\
\text { exaggerated. }\end{array}$ & 14 \\
\hline & $\begin{array}{l}\text { If things continue on } \\
\text { their present course, } \\
\text { we will soon } \\
\text { experience a major } \\
\text { ecological catastrophe }\end{array}$ & 15 \\
\hline
\end{tabular}

\subsubsection{Validity}

Validity is determined by Pearson correlation (r). The results of Pearson correlation of the sample is shown as follows:

Table 2. Calculation result validity nep scale questionnaire

\begin{tabular}{|c|c|c|c|}
\hline Item & $\mathbf{r}$ & Significant & Conclusions \\
\hline 1 & 0,188 & 0,116 & Not valid \\
\hline 2 & 0,046 & 0,706 & Not valid \\
\hline 3 & 0,331 & 0,005 & Valid \\
\hline 4 & 0,428 & 0,001 & Valid \\
\hline 5 & $-0,151$ & 0,210 & Not valid \\
\hline 6 & $-0,038$ & 0,752 & Not valid \\
\hline 7 & 0,568 & 0,001 & Valid \\
\hline 8 & 0,161 & 0,179 & Not valid \\
\hline 9 & 0,434 & 0,001 & Valid \\
\hline 10 & $-0,023$ & 0,851 & Not valid \\
\hline 11 & 0,491 & 0,001 & Valid \\
\hline 12 & 0,451 & 0,001 & Valid \\
\hline 13 & 0,564 & 0,001 & Valid \\
\hline 14 & 0,411 & 0,001 & Valid \\
\hline 15 & 0,421 & 0,001 & Valid \\
\hline
\end{tabular}

The results indicate that the item is a valid item number $3,4,7,9,11,12,13,14$ and 15 . Therefore, these items are then taken as an item to be used for the calculation of reliability.

\subsubsection{Reliability}

Calculation of reliability using Cronbach's Alpha parameter. The results of calculation of reliability on items that have valid ( 9 items) show the reliability of 0.658 . This value is deemed reliable because the limit of reliability is 0.6 [14]

\subsection{Socio-economic status and institution}

Organizations or socio-economic status is an organized way of the urban population according to social stratification, political systems, and economic systems [15]. Socio-economic status was approached with a total income of the household and the highest education of the household. The parameters used are the logarithm multiplication between the level of education and income levels. The level of education consists of seven levels: Elementary (1), SMP (2), High School (3), Diploma (4), S1 (5), S2 (6), and S3 (7) which refers to the highest level of education held family members. Income alone is numerical data that shows the total amount of earnings of all family members in rupiah unit. Measurements are made through a questionnaire.

Institutions in this study were approached by their family members who work in the fields of education, health, leisure, and commerce. If there is, then the sample is given the index 2 while no indexed 1. Value institution itself is the multiplication of educational 
status, health, and comfort divided by trade status. This is because the status of education, health, and comfort should be oriented pro-environment because of their obligation to promote sustainability or a special focus on aspects of sustainability. Meanwhile, the trade is viewed, Therefore, if a house has four professions, the total score is $2 \times 2 \times 2 / 2=4$. If a house has a profession of education, health, and comfort, but no trade profession, then the total score is 6 . it is obtained through a questionnaire.

\section{Result}

Table 3 shows the descriptive statistical study respondents. The majority of families have the highest level of high school (43 of 103 respondents). The average income of respondents was IDR 4,297,000. 13 respondents working in education, four work in the field of hospitality, 8 working in the health sector, and 53 working in the field of trade.

Table 3. Descriptive statistics respondents

\begin{tabular}{|c|c|}
\hline \multicolumn{2}{|l|}{ Last Education } \\
\hline Primary school & 3 \\
\hline Junior high school & 4 \\
\hline Senior high school & 43 \\
\hline Diploma & 11 \\
\hline Bachelor & 35 \\
\hline Postgraduate & 7 \\
\hline \multicolumn{2}{|l|}{ Income } \\
\hline Mean & 4.297 .000 \\
\hline Standard Deviation & 3.583 .500 \\
\hline \multicolumn{2}{|l|}{ Institutions } \\
\hline Educational institutions & 13 \\
\hline The hospitality institutions & 4 \\
\hline Health institutions & 8 \\
\hline Trading institutions & 53 \\
\hline
\end{tabular}

The potential of the relationship between socioeconomic status and pro-environmental institutions with environmental concern level, tested through regression analysis using SPSS software version 20. Figure 2 shows the normality of residual regression results is a prerequisite for regression analysis. Observations in Figure 3 shows that the results of the regression residuals clear that normal distribution so that the linear regression model can be accepted as a method of data analysis.

\section{Normal P.P Plot of Regression Standardized Residual}

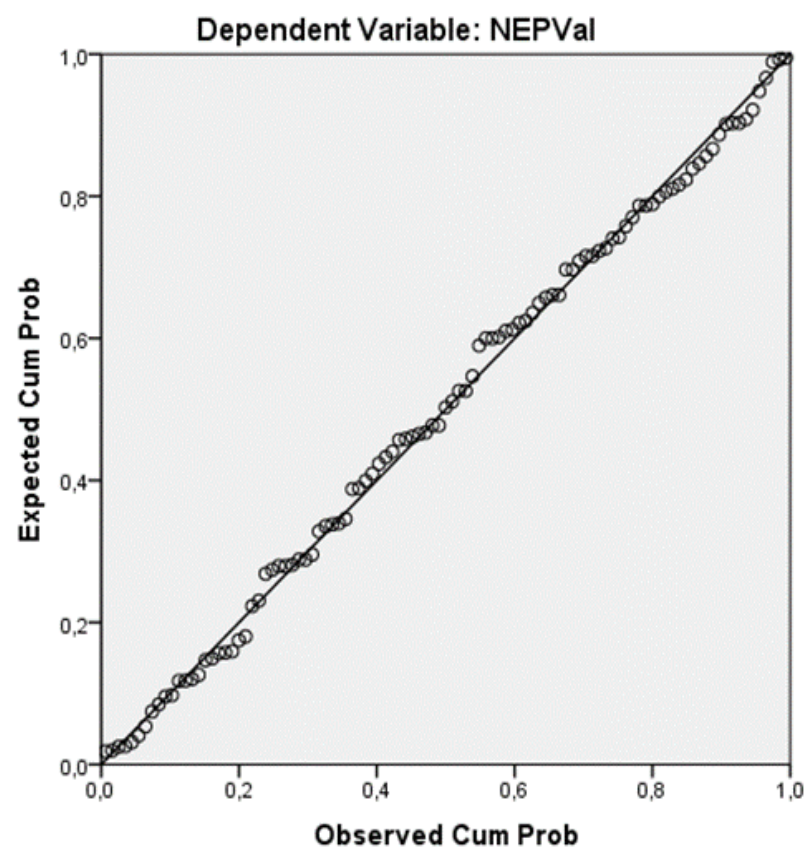

Fig. 2. Graph normality of regression results

Figure 3 shows a scatter plot of the regression residuals. Spread of points do not form a clear pattern, so it can be inferred that the regression model having no problem with heteroscedasticity

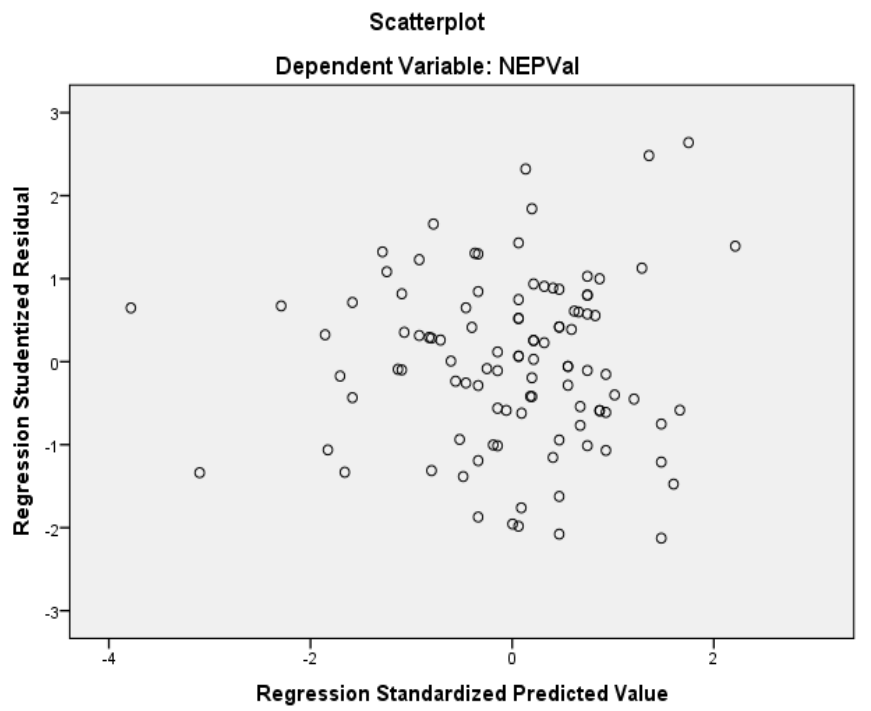

Fig. 3. Scatter plot regression residual

To see the relationship between variables, we calculate regression by putting variable socioeconomic status as a single variable that is the natural logarithm of the level of income and education level of respondents. This is done because the amount of income has a very great value compared to other indicators, as calculated in units of currency. The regression results are shown in Table 4. It appears that the effect weak institutions to environmental concerns while socioeconomic status had no significant effect on environmental awareness. But the influence of institutions on environmental concerns 
actually negative. That is, the person becomes a member of a pro-environmental institution, the more he behaves not care about the environment.

Table 4. Calculation results of multiple regression socioeconomic status and institution of the nep scale

\section{Coefficients}

\begin{tabular}{|c|c|c|c|c|c|}
\hline \multirow{2}{*}{ Model } & \multicolumn{2}{|c|}{$\begin{array}{c}\text { Unstandardized } \\
\text { Coefficients }\end{array}$} & \multirow{2}{*}{$\begin{array}{c}\begin{array}{c}\text { Standardized } \\
\text { Coefficients }\end{array} \\
\text { Beta }\end{array}$} & \multirow{2}{*}{$\mathbf{t}$} & \multirow{2}{*}{ Sig. } \\
\hline & B & $\begin{array}{l}\text { Std. } \\
\text { Error }\end{array}$ & & & \\
\hline (Constant) & 24,693 & 1,391 & & $\begin{array}{c}17,74 \\
7\end{array}$ & ,000 \\
\hline 1 Institution & $-1,214$ & 680 &,- 175 & $\begin{array}{c}- \\
1,785\end{array}$ & ,077 \\
\hline $\begin{array}{c}\text { Ln (Education } \\
\text { x Income) }\end{array}$ &,- 738 & , 486 &,- 149 & $\begin{array}{c}- \\
1,519\end{array}$ & ,132 \\
\hline
\end{tabular}

a. Dependent Variable: NEP Scale

The above results show that the institutions that developed among the people in the three housing destructive rather than constructive for the environment. Education does not give a positive impetus on environmentally friendly behavior. In contrast, higher education justifies one's behavior to the consumer and not environmentally friendly behavior, such as in educational institutions. There is no awareness to encourage students and teachers that are environmentally friendly. Health institutions are also not concerned with efforts to encourage patients and health care to behave environmentally friendly. Meanwhile, institutions are not sustainable comfort and are consumptive. Instead, institutions trade show's positive attitude. Orientation pro-environmental regulation of trade can be understood as respondents generally a small enterprise (SMEs) which have stalls with low environmental impact and has little environmental impact rising (eg. garbage in large quantities in the store), will affect the economic value obtained traders seek profit. Therefore, they will try to keep the environment location.

\section{Conclusion}

The above results indicate that to increase the level of environmental concern, sociological intervention is required. In this study, it was found that variable institutions affect the level of environmental concern was negative and weak. This is because institutions housing residents in developing countries have consumer behavior and less concerned with the environment. In other words, Institution as one form of social organization has a negative role in environmental concerns, therefore in order that the institutions have a positive impact, it must do some activities as follows:

- The government should strengthen environmental education curriculum so as to encourage the younger generation to love the environment and strive to reduce environmental impact at their residence. This is an easy program because there are no sociological barriers in urban communities. Urban communities are relatively liberal and scientific. Would be different if we did in the marginal communities that have a conservative and fatalistic attitude.

- Health institutions more easily integrated with the environmental concerns, because the quality of meteorological would have a direct impact on human health. Therefore, the health center should be warned about the danger of pollution or destruction of the environment and the importance of healthy behavior.

- Hospitality institutions should use components that are more natural in every activity, for example by extending the trees or by replacing manufacturing materials with natural materials. of course, these activities are not attractive to local travelers who are accustomed to tropical life, but it will attract foreign tourists are more interested in the local characteristics. They come to Indonesia not to find something that can be found in his own country. They want the typical situation of Indonesia and this is indicated by a tropical environment in harmony with nature Indonesia. For example, the guest house can be made with the concept of traditional architecture including the typical environment of Palembang city in the past.

- Trade is the most difficult institutions to be triggered environmental changes for the better because the essence of trade is the exploitation of natural resources into goods of human needs. exploitation caused environmental pollution, not least in the form of smoke from a factory or waste in traditional markets. The rational step that can be done to make this trade regulation as the trigger for the better is to expect the public awareness and efforts to forcefully through trade laws more restrictive.

\section{References}

1. R. Kutter, W. Information Strategies in Websites for Sustainable Consumption: An Exploration of the EcoRunner Tool, (2009).

2. R. Bechtel \& Churchman, A. (Eds.). (2003). Handbook of environmental psychology. John Wiley \& Sons, (2003).

3. R. Schefold., Nas, P., \& Domenig, G. (Eds.). Indonesian Houses: Tradition and transformation in vernacular architecture. NUS Press, (2004).

4. S. Clayton., Myers, G. Conservation Psychology: Understanding and Promoting Human Care for Nature. John Wiley and Sons, (2015).

5. M. Bodur. Sarigollu, E. Environmental Sensitivity in a Developing Country: Consumer Classification and Implications. J. Environment and Behavior, 37 (4), 487-510, (2005)

6. T. Milfont, L. \& Duckitt, J. J. Environmental Psychology, 24, 3, (2004)

7. L. Zelezny, C. Chua, P. P. \& Aldrich, C. J. Social issues, 56, 3, (2000)

8. M. Floyd. Race, Ethnicity, and Use of the National Park System. Social Science Research Review, 1(2), (1999)

9. A. Mareck, F. Acquiring Biospheric Literacy: Discursive Tools, Situated Learning, and the 
10. Rhetoric of Use. In Goggin, P.N (ed), Rhetorics, Literacies, and Narratives of Sustainability. Routledge, (2010)

11. R. Godfrey, J. Risky. Messages to Whom?: Understanding Our Toleration for Risk Through an Examination of Values. ProQuest, (2008)

12. M. Pelling. Resilience and Transformation. In Pelling, Mark, David Manuel-Navarrete, and Michael Redclift, eds. Climate change and the crisis of capitalism: a chance to reclaim, self, society and nature. Routledge, (2012).

13. J. Porter, R \& Howell, F. M. (2012). Geographical sociology: Theoretical foundations and methodological applications in the sociology of location (Vol. 105). Springer Science \& Business Media, (2012)

14. Pemerintah Kota Palembang. Peta Kota Palembang, (2012)

15. J. Hair, F. Anderson, R. E., Tatham, R. L., \& William, C. (1998). Multivariate data analysis. (1998)

16. R. Palen. Emergence of Cities, (2006) http://www.bolender.com/Sociology/Palen/Palen $\% 2$ 02.htm. Accessed on July 12nd 2016. 